Article

\title{
Bullying among Teens: Are Ethnicity and Race Risk Factors for Victimization? A Bibliometric Research
}

\author{
Arturo Fuentes Cabrera, Antonio José Moreno Guerrero ${ }^{\mathbb{D}}$, José Santiago Pozo Sánchez ${ }^{\mathbb{D}}$ and \\ Antonio-Manuel Rodríguez-García *(D)
}

Department of Didactics and School Organization, University of Granada, Campus of Ceuta, 51001 Ceuta, Spain

* Correspondence: arodrigu@ugr.es

Received: 25 June 2019; Accepted: 14 August 2019; Published: 20 August 2019

\begin{abstract}
Bullying is a problematic situation that negatively affects thousands of children and adolescents in today's world. The multicultural society resulting from globalization has caused different reactions throughout society. In the school context, some authors indicate that ethnicity and race are risk factors for being victims of bullying. Therefore, the purpose of this paper was to analyze the scientific production on racial or ethnic bullying with the greatest impact at present, considering nine variables: Publication date, authors, organizations, countries, journals, type of document, area of research, language, and reference with more impact (cites). We conducted a bibliometric study through systematic review, documentary quantification, and data visualization techniques. We analyzed 831 documents, with a notable increase in recent years (2011-2019), highlighting the production from Dewey Cornell (University of Virginia, Charlottesville, VA, USA). On the other hand, the results showed that ethnic identity constitutes a differential factor in harassment appearing, accompanied by very poor socio-economic and cultural levels favoring depressive tendencies and drug consumption in the ethnic harassed. In short, bullying has a negative impact both physically and psychologically on the victims. For this reason, we must continue to work from the school context to eradicate the situation that is affecting more and more people.
\end{abstract}

Keywords: bullying; cyberbullying; ethnicity; racism; bibliometric study

\section{Introduction}

Nowadays, in our society, we detect problematic and complex situations to solve that occur-above all-in the educational field and imply the disadvantage of some students in respect to others. Among these types of situations, we can highlight bullying, which can be defined as the act of violence that people exert against each other repeatedly over time and whose basis sustains an imbalance of power [1].

As in other fields, a new era is also opening up for the world of violence in the classroom because of the use of information and communication technologies [2]. The bad intention, sometimes with which students can use the internet and mobile phones, generates a new type of aggression called cyberbullying [3]. All these aspects of violence are beginning to be considered a major public health problem [4], specifically for children [5], sometimes generating adverse behavior [6] and even leading to suicidal behavior in young people [7].

The variants that can be found in this type of harassment are very diverse, and no specific profile can be established [8]. Even so, different signs shown by the victims can be indicators of cyberbullying. The signs we are talking about are aspects that victims externalize when they are immersed in a situation of harassment, such as depression, anxiety, or anger, understood as internal problems to the subject, or external elements such as aggression or the use of narcotic substances [9]. 
Other signs the victims usually show are: reduced physical activity [10], decreased sleep duration [11], low self-esteem, difficulties in social skills [12], poor body image, poor eating habits [13], and consumption of alcoholic beverages [14]. More specifically, subjects who suffer cyberbullying tend to have mental health problems, engage in substance abuse, become overweight, and use video games for three or more hours a day [15].

As with certain minorities, ethnic minorities are prone to being harassment victims [16], more so for first-generation immigrants than second-generation ones [17]. It is difficult to determine group differences in harassment actions [18]. There are factors such as ethnic identity that do have a direct influence [19], and even other factors such as the existence of low or very low socio-economic and cultural status [20]. In addition, an association is identified between the state of racial harassment and drug use [21]. Those who receive ethnic harassment have weak self-control, prefer to use external coping mechanisms and give up easily, experience loneliness, social anxiety, and withdrawal from the social environment $[22,23]$.

Other elements that place certain groups at risk of harassment are sexual tendencies (e.g., homosexuality) [24], religious practice [25], and different types of functional diversity [26], encompassing a wide threshold of possibilities.

Even so, there are elements that make it possible to glimpse possible solutions or responses to cases of harassment. One of them is young people's positive perception of teachers, which reduces the risk of victimization and perpetration [27]. Another element is the expression of empathy of students with harassed classmates [28]. The school climate and parental involvement mitigate the effects of bullying [29], and even the control they can exert over their children [30]. Another element of vital importance is peer tutoring, which allows for predicting the decrease of intimidation, victimization, struggle, and anger [31].

It should be kept in mind that in order to act and prevent bullying of adolescents, those most vulnerable to harassment must be identified. Threatening behaviors and the possibility that a student may report them should be examined [32].

In certain areas, bullying is being prevented and detected using gambling-based teaching methods (gamification) and integrating less common elements such as social interaction, augmented reality, and mobile phones with educational settings [33].

\section{Materials and Methods}

This was a bibliometric study by literature review, documentary quantification, and data visualization techniques [34-36].

The general objective of this paper was to analyze the scientific production with the greatest impact on racial or ethnic bullying in Scopus (S) and Web of Science (W). In addition, this study aimed to achieve the following specific objectives:

(1) To analyze scientific production from a diachronic perspective;

(2) To study the most prolific authors, institutions, countries, and journals in terms of the object of research;

(3) To review the type of document, the area of publication, and the language in which it is published;

(4) To carry out an analysis of the content of the titles, abstracts, and keywords of the documents, taking as a reference the object of study (bullying) and the related variables: ethnicity, race, and perspective of the victims.

\section{Procedure and Selection of the Sample}

In order to achieve the above objectives, we carried out different thematic searches (April-May 2019) in the Scopus database (SJR) and in the main collection of the Web of Science (Science Citation Index, Social Science Citation Index and Arts \& Humanities Citation Index). The keywords were 
delimited through the ERIC Thesaurus, and the following were selected: "racial bullying" (RB) and "ethnic bullying" (EB).

The total sample consisted of $n=831$ documents. The search process is represented through the PRISMA flowchart (Figure 1), where we depict the flow of information through the different phases of review [37] and in which we contemplated nine scientific production variables.

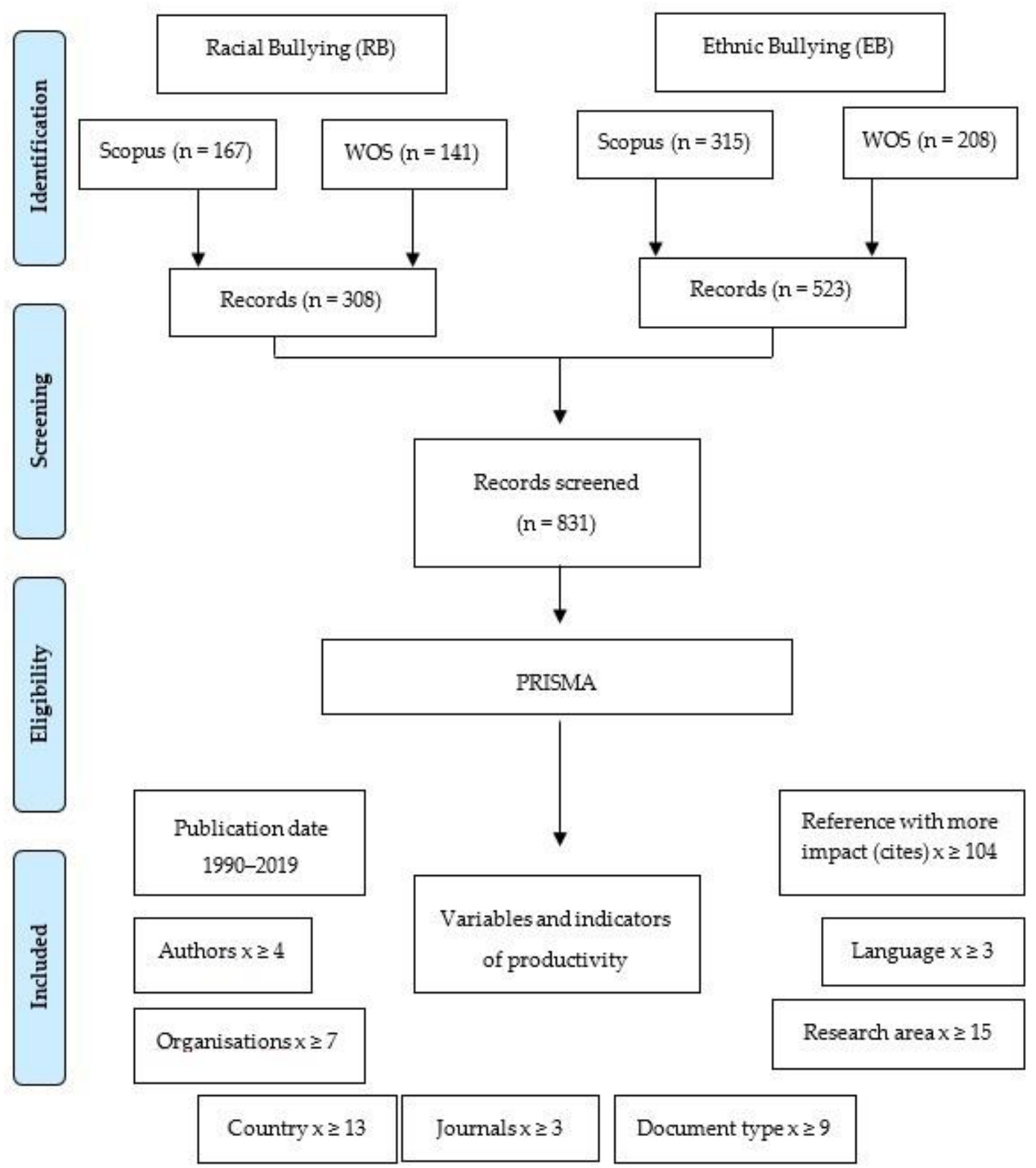

Figure 1. PRISMA flow diagram and production variables.

\section{Results}

We present the results according to each of the research objectives: 


\subsection{Diachronic Productivity}

The following table (Table 1 ) shows the diachronic analysis of the scientific literature distinguishing the four searches carried out in the two multidisciplinary databases.

Table 1. Analysis of scientific production from a time perspective.

\begin{tabular}{ccccc}
\hline & \multicolumn{2}{c}{ Scopus (S) } & \multicolumn{2}{c}{ Web of Science (W) } \\
\hline Triennium & Racial Bullying & Ethnic Bullying & Racial Bullying & Ethnic Bullying \\
\hline $\mathbf{1 9 9 0 - 1 9 9 2}$ & 1 & 2 & 1 & 1 \\
$\mathbf{1 9 9 3 - 1 9 9 5}$ & 1 & 3 & 1 & 4 \\
$\mathbf{1 9 9 6 - 1 9 9 8}$ & 1 & 2 & 1 & 1 \\
$\mathbf{1 9 9 9 - 2 0 0 1}$ & 2 & 4 & 1 & 3 \\
$\mathbf{2 0 0 2 - 2 0 0 4}$ & 7 & 14 & 6 & 10 \\
$\mathbf{2 0 0 5 - 2 0 0 7}$ & 9 & 23 & 9 & 18 \\
$\mathbf{2 0 0 8 - 2 0 1 0}$ & 13 & 30 & 16 & 17 \\
$\mathbf{2 0 1 1 - 2 0 1 3}$ & 36 & 68 & 21 & 30 \\
$\mathbf{2 0 1 4 - 2 0 1 6}$ & 42 & 80 & 43 & 57 \\
$\mathbf{2 0 1 7 - 2 0 1 9}$ & 55 & 89 & 42 & 67 \\
\hline
\end{tabular}

More specifically, as we can see in Figure 2, the research topic is in a phase of exponential growth that began in the three-year period 1999-2001. However, the greatest scientific production was concentrated in recent years, so we are dealing with a research topic that generates concern for the scientific community in the field of education.

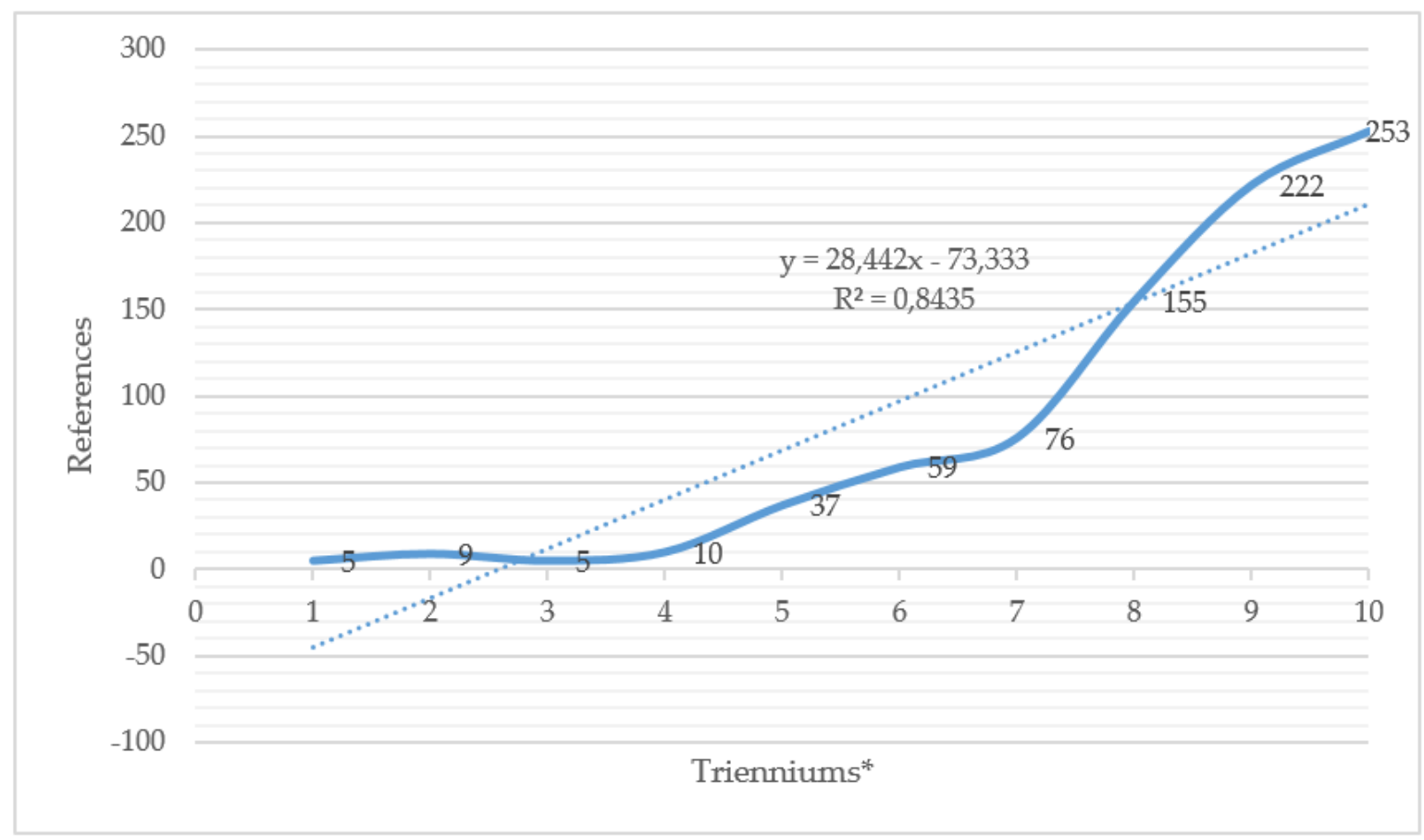

Figure 2. Diachronic productivity. *Trienniums: 1 (1990-1992), 2 (1993-1995), 3 (1996-1998), 4 (1999-2001), 5 (2002-2004), 6 (2005-2007), 7 (2008-2010), 8 (2011-2013), 9 (2014-2016), 10 (2017-2019).

\subsection{Productivity of Authors, Geography, Research Area, and Type of Document}

As for the authors of the publications, it is worth highlighting an important production with respect to the subjects of authors such as Cornell, D., Peskin, M.F., Hong, J.S., and Tortolero, S.R., as their presence is found in both databases and terms associated with the search. There have also been other authors with an important number of publications, as seen in the following table (Table 2). 
Table 2. Authors with the greatest scientific production on the subject.

\begin{tabular}{ccccc}
\hline \multirow{2}{*}{ Author } & \multicolumn{2}{c}{ Scopus (S) } & \multicolumn{2}{c}{ Web of Science (W) } \\
\cline { 2 - 5 } & Racial Bullying & Ethnic Bullying & Racial Bullying & Ethnic Bullying \\
\hline Cornell, D. & 3 & 6 & 2 & 5 \\
Hong, J.S. & 4 & 2 & 3 & 3 \\
Peskin, M.F. & 3 & 4 & 2 & 3 \\
Tortolero, S.R. & 4 & 4 & 2 & 2 \\
Eisenberg, M.E. & 3 & 3 & 2 & 3 \\
Neumark-Sztainer, & 3 & 3 & 2 & 3 \\
D. & 1 & 4 & 2 & 4 \\
Vitoroulis, I. & - & 10 & - & - \\
Elamé, E. & 3 & 3 & 3 & 1 \\
Espelage, D.L. & 1 & 4 & 1 & 2 \\
Craig, W. & 1 & 4 & - & 1 \\
Graham, S. & 3 & 1 & 2 & - \\
Lewis, D. & 3 & - & 3 & - \\
Chen, W.C. & - & 4 & - & \\
Vaillancourt, T. & & & & \\
\hline
\end{tabular}

As for the institutions from which the scientific research and productions analyzed in this study came (Table 3), it is worth highlighting the scientific production of the University of Virginia, as well as the King's College London and the University of Virginia.

Table 3. Institutions with notable research production.

\begin{tabular}{|c|c|c|c|c|}
\hline \multirow{2}{*}{ Institution } & \multicolumn{2}{|c|}{ Scopus (S) } & \multicolumn{2}{|c|}{ WoS (W) } \\
\hline & Racial Bullying & Ethnic Bullying & Racial Bullying & Ethnic Bullying \\
\hline University of Virginia & 6 & 8 & 5 & 6 \\
\hline King's College London & 2 & 11 & 1 & 5 \\
\hline University of California & 2 & 9 & 1 & 7 \\
\hline University of Minnesota Twin Cities & 4 & 6 & 3 & 5 \\
\hline Università Ca' Foscari Venezia & 2 & 10 & 1 & 4 \\
\hline $\begin{array}{l}\text { The University of North Carolina at } \\
\text { Chapel Hill }\end{array}$ & 6 & 6 & 2 & 1 \\
\hline Wayne State University & 5 & 2 & 4 & 4 \\
\hline $\begin{array}{l}\text { University of Minnesota School of } \\
\text { Public Health }\end{array}$ & 3 & 5 & 1 & 5 \\
\hline University of Pennsylvania & 5 & 2 & 5 & 2 \\
\hline Michigan State University & 4 & 2 & 4 & 2 \\
\hline $\begin{array}{l}\text { University of Texas Health Science } \\
\text { Center at Houston }\end{array}$ & 4 & 5 & 2 & 1 \\
\hline Bar-Ilan University & 1 & 6 & 1 & 3 \\
\hline Boston College & 4 & 1 & 3 & 2 \\
\hline Harvard Medical School & 4 & 2 & 2 & 2 \\
\hline Ohio State University & 4 & 2 & 3 & 1 \\
\hline Queen's University, Kingston & 1 & 5 & 2 & 2 \\
\hline $\begin{array}{c}\text { University of Illinois at } \\
\text { Urbana-Champaign }\end{array}$ & 4 & 1 & 4 & 1 \\
\hline University of Ottawa, Canada & 1 & 5 & 1 & 3 \\
\hline University of Hawaii at Manoa & 2 & 5 & 1 & 1 \\
\hline University of Texas at Austin & 2 & 5 & 1 & 1 \\
\hline Children's Hospital Boston & 4 & 2 & 1 & 1 \\
\hline $\begin{array}{c}\text { Center for Disease Control and } \\
\text { Prevention }\end{array}$ & 2 & 5 & - & - \\
\hline
\end{tabular}

In terms of geographical productivity (Table 4), the United States was the country with the most publications on the subject, surpassing half of those produced so far, with a very notable number of 464 publications. At a great distance, the United Kingdom followed with 116. 
Table 4. Countries with the highest scientific production.

\begin{tabular}{ccccc}
\hline \multirow{2}{*}{ Country } & \multicolumn{2}{c}{ Scopus (S) } & \multicolumn{2}{c}{ WoS (W) } \\
\cline { 2 - 5 } & Racial Bullying & Ethnic Bullying & Racial Bullying & Ethnic Bullying \\
\hline United States & 115 & 157 & 89 & 103 \\
United Kingdom & 13 & 54 & 12 & 37 \\
Canada & 13 & 19 & 12 & 8 \\
Australia & 6 & 15 & 9 & 10 \\
Italy & 2 & 15 & 2 & 7 \\
Spain & 2 & 6 & 4 & 6 \\
South Korea & 4 & 5 & 3 & 6 \\
Netherlands & - & 10 & 1 & 5 \\
Israel & 1 & 9 & 1 & 6 \\
New Zealand & - & 6 & 1 & 3 \\
Sweden & 1 & 8 & 2 & 3 \\
Brazil & 4 & 3 & & 7 \\
\hline
\end{tabular}

In Table 5 we can observe the journals in which the most research has been published on the studied topics, distinguishing around the two large databases of scientific production. Journals such as Journal of Youth Adolescence and Journal of Adolescence Health are responsible for a large part of this type of publication and are highlighted in both databases.

Table 5. Most prolific journals (Scopus and WoS).

\begin{tabular}{|c|c|c|c|c|}
\hline \multirow{2}{*}{ Journals } & \multicolumn{2}{|c|}{ Scopus (S) } & \multicolumn{2}{|c|}{ WoS (W) } \\
\hline & Racial Bullying & Ethnic Bullying & Racial Bullying & Ethnic Bullying \\
\hline $\begin{array}{l}\text { Journal of Youth And } \\
\text { Adolescence }\end{array}$ & 7 & 15 & 6 & 9 \\
\hline $\begin{array}{c}\text { Journal of Adolescent } \\
\text { Health }\end{array}$ & 6 & 14 & 5 & 5 \\
\hline Journal of Adolescence & 4 & 6 & 4 & 7 \\
\hline Journal of School Violence & 4 & 2 & - & - \\
\hline $\begin{array}{l}\text { Children and Youth } \\
\text { Services Review }\end{array}$ & 3 & 1 & - & - \\
\hline $\begin{array}{c}\text { Race Ethnicity and } \\
\text { Education }\end{array}$ & 3 & 2 & - & - \\
\hline Discriminatory Bullying A & & & & \\
\hline $\begin{array}{c}\text { New Intercultural } \\
\text { Challenge }\end{array}$ & - & 10 & - & - \\
\hline Child Abuse and Neglect & - & 8 & & \\
\hline Journal of School Health & 1 & 6 & 4 & 6 \\
\hline Educational Research & - & - & - & 6 \\
\hline Pediatric & - & - & 3 & - \\
\hline Plos One & 3 & 4 & 3 & 3 \\
\hline
\end{tabular}

As for the variable type of document (Table 6), we observed that the scientific article stands out above the rest, being notable its growth in the last years, and being an indisputable protagonist of this type of publication. 
Table 6. Document type.

\begin{tabular}{ccccc}
\hline \multirow{2}{*}{ Document type } & \multicolumn{2}{c}{ Scopus (S) } & \multicolumn{2}{c}{ WoS (W) } \\
\cline { 2 - 5 } & Racial Bullying & Ethnic Bullying & Racial Bullying & Ethnic Bullying \\
\hline Article & 135 & 256 & 123 & 180 \\
Review & 13 & 19 & 5 & 11 \\
Proceedings paper & - & - & 8 & 7 \\
Book Chapter & 8 & 18 & 4 & 7 \\
Conference Paper & 6 & 5 & - & - \\
Book & 3 & 5 & - & 1 \\
\hline
\end{tabular}

The area of publication (Tables 7 and 8), has also been recognized as indispensable when carrying out this study (highlighting in the database SJR those of Medicine and Psychology), the latter also being the undisputed protagonist in the production of the database of Web of Science. This is due to the fact that bullying has been studied from different areas of knowledge, with medicine and psychology being the fields in which most research has been carried out to date.

Table 7. Publication areas from Scopus.

\begin{tabular}{cccc}
\hline Area & \multicolumn{3}{c}{ Scopus } \\
\cline { 2 - 4 } & Racial Bullying & Ethnic Bullying & Total \\
\hline Arts and Humanities & 11 & 29 & 40 \\
Medicine & 60 & 150 & 210 \\
Nursing & 9 & 11 & 20 \\
Psychology & 61 & 150 & 211 \\
Social Sciences & 85 & 127 & 212 \\
\hline
\end{tabular}

Table 8. Publication areas from Web of Science.

\begin{tabular}{cccc}
\hline Area & \multicolumn{3}{c}{ WoS } \\
\cline { 2 - 4 } & Racial Bullying & Ethnic Bullying & Total \\
\hline Education Educational & 18 & 29 & 47 \\
Research & 9 & 6 & 15 \\
Ethnic Studies & 9 & 9 & 18 \\
Family Studies & 12 & 14 & 26 \\
Pediatrics & 49 & 98 & 147 \\
Psychology & 27 & 32 & 59 \\
Public Environmental & & & \\
Occupational Health & &
\end{tabular}

The language most commonly used in these publications is, indisputably, English. It accounted for the majority (Table 9) of the literary production housed in these databases with respect to the subject studied.

Table 9. Language of publication.

\begin{tabular}{cccccc}
\hline \multirow{2}{*}{ Language } & \multicolumn{2}{c}{ Scopus (S) } & \multicolumn{2}{c}{ Web of Science (W) } & \multirow{2}{*}{ Total } \\
\cline { 2 - 5 } & $\begin{array}{c}\text { Racial } \\
\text { Bullying }\end{array}$ & $\begin{array}{c}\text { Ethnic } \\
\text { Bullying }\end{array}$ & $\begin{array}{c}\text { Racial } \\
\text { Bullying }\end{array}$ & $\begin{array}{c}\text { Ethnic } \\
\text { Bullying }\end{array}$ & \\
\hline Spanish & - & 2 & - & 1 & 3 \\
English & 167 & 310 & 139 & 202 & 818 \\
Portuguese & 1 & - & 2 & 1 & 4 \\
\hline
\end{tabular}


Finally, there were two articles which, due to their title, summary and keywords, are highly relevant to what has been studied in the present work and have a large number of citations in the databases studied. These can be observed in the table below (Table 10).

Table 10. Most cited references.

\begin{tabular}{|c|c|c|c|c|c|}
\hline Author & Year & Title & Journal & Cites (S) & Cites (W) \\
\hline $\begin{array}{c}\text { Spriggs, } \\
\text { Iannotti, } \\
\text { Nansel and } \\
\text { Haynie [38] }\end{array}$ & 2007 & $\begin{array}{l}\text { Adolescent Bullying } \\
\text { Involvement and } \\
\text { Perceived Family, Peer and } \\
\text { School Relations: } \\
\text { Commonalities and } \\
\text { Differences Across } \\
\text { Race/Ethnicity }\end{array}$ & $\begin{array}{c}\text { Journal of } \\
\text { Adolescent } \\
\text { Health }\end{array}$ & 268 & 239 \\
\hline $\begin{array}{c}\text { Sawyer, } \\
\text { Bradshaw and } \\
\text { O'Brennan [39] }\end{array}$ & 2008 & $\begin{array}{l}\text { Examining Ethnic, Gender, } \\
\text { and Developmental } \\
\text { Differences in the Way } \\
\text { Children Report Being a } \\
\text { Victim of "Bullying" on } \\
\text { Self-Report Measures }\end{array}$ & $\begin{array}{c}\text { Journal of } \\
\text { Adolescent } \\
\text { Health }\end{array}$ & 118 & 104 \\
\hline
\end{tabular}

\subsection{Content Analysis of Titles, Abstracts, and Keywords}

The co-occurrence analysis of word frequency $(x \geq 5)$ applied to the title, abstract, and keywords of the works (article, conference paper, and book chapter, among others) determined the existence of five thematic clusters (Figure 3). They allowed us to infer that research on current bullying focuses on bullying which occurs amongst children and adolescents, especially against minority groups for reasons of ethnicity, racism, or discrimination.

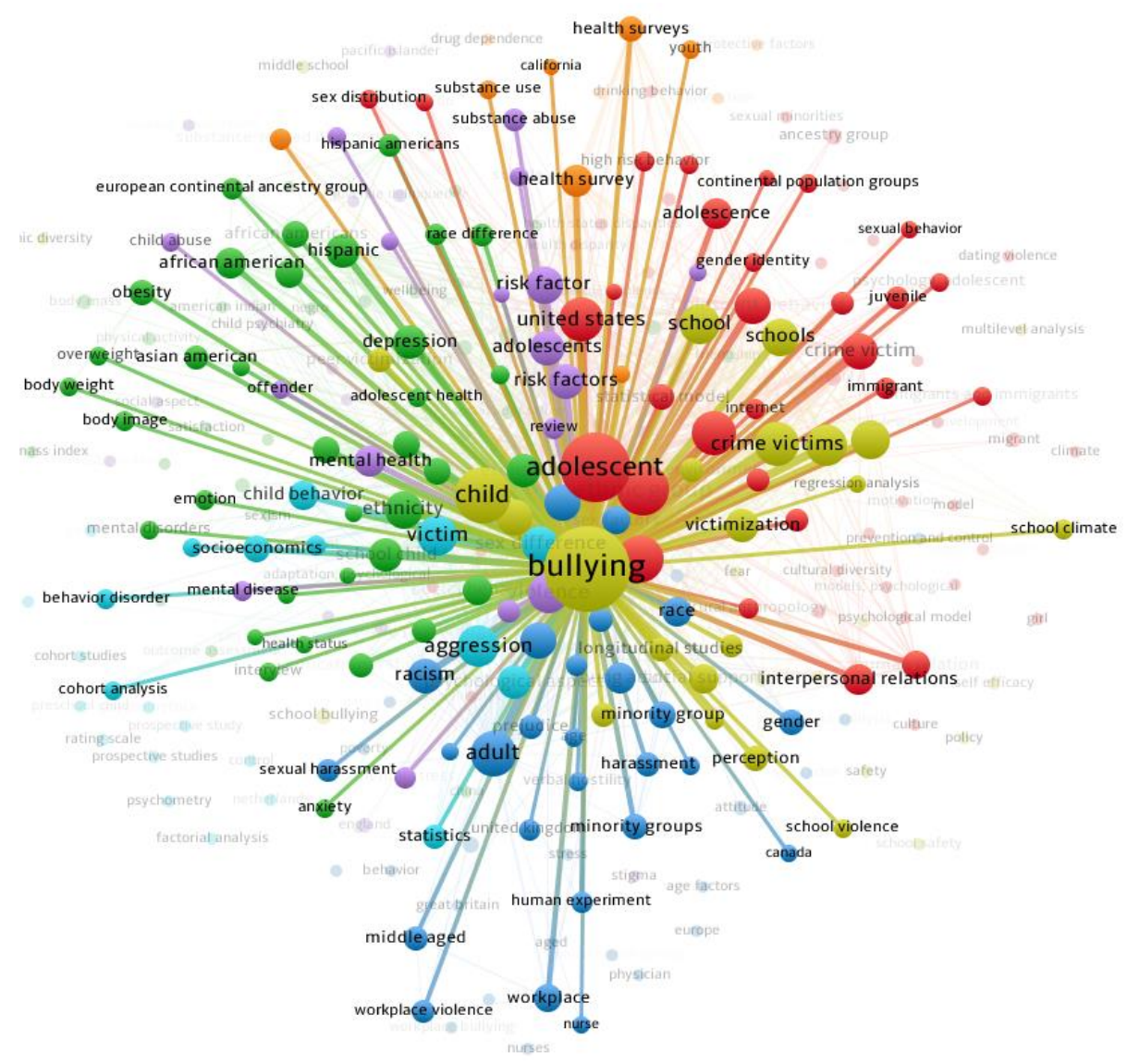

Figure 3. General co-occurrence analysis. 
More specifically, in attention to ethnicity, we highlight the greater presence of studies on bullying among teenagers in the US school context towards populations of Hispanic, Caucasian, African, and Asian origins. (Figure 4). On the other hand, those studies that focused their perspective on racist bullying were mostly about African-American populations.

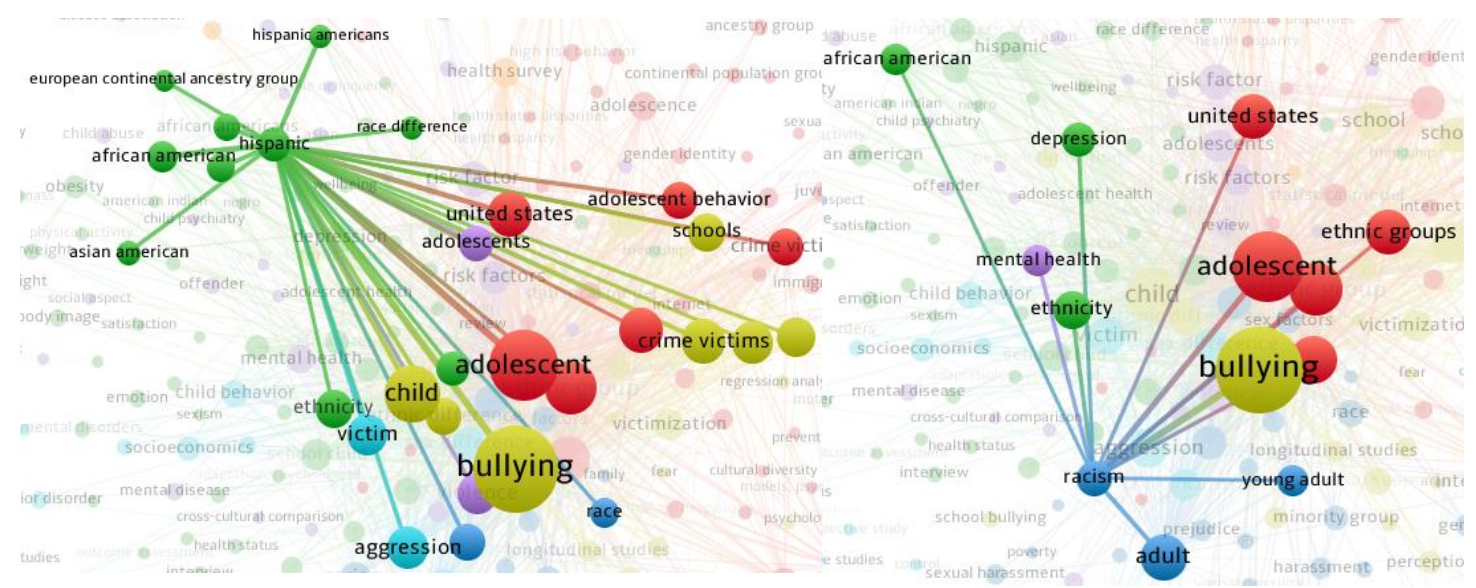

Figure 4. Co-occurrence analysis: ethnicity and racism.

Racial differences became one of the motivations among adolescents to victimize a person to bullying (Figure 5). The same happened with ethnic differences, causing negative consequences in victims such as aggression and health problems (physical and psychological).
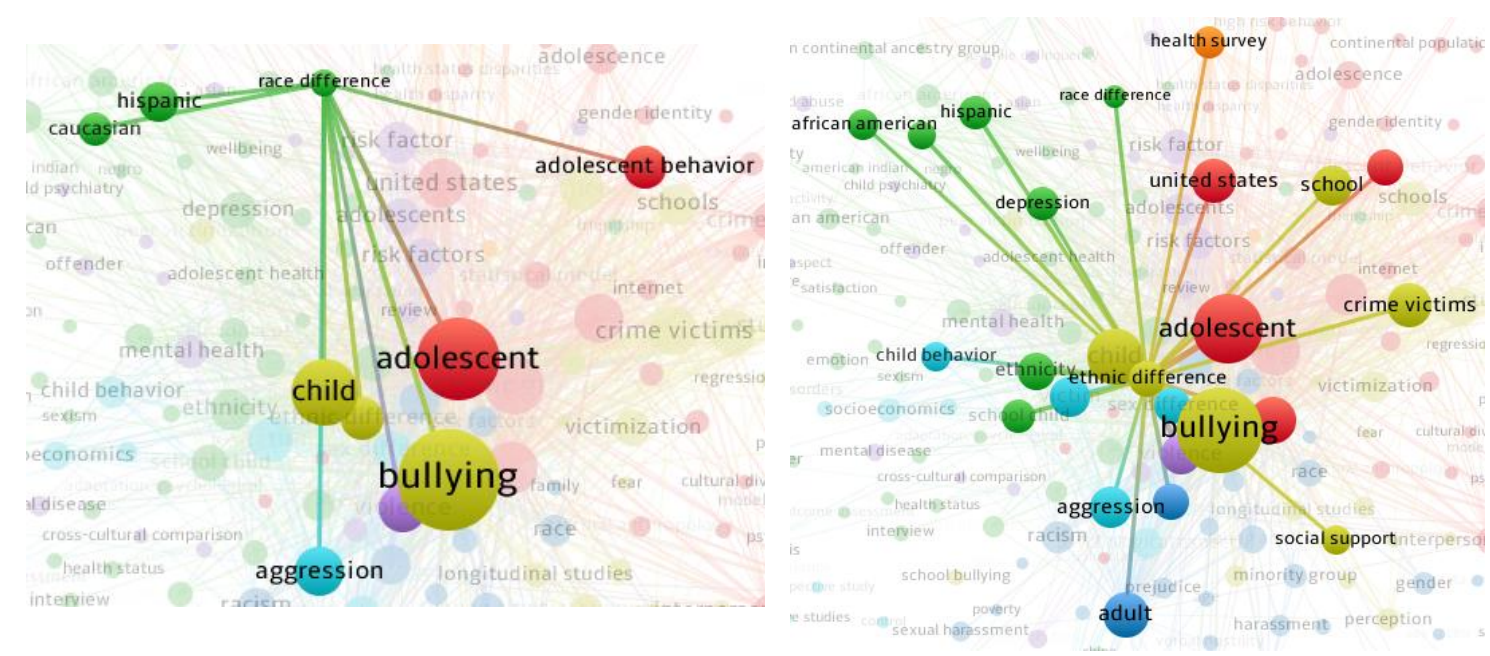

Figure 5. Co-occurrence analysis: racial and ethnic differences.

The profile of the victim was studied from different perspectives, such as risk factors for being a victim, ethnic origin, incidence in interpersonal relations, the context in which it occurs, and social status, among others (Figure 6). 


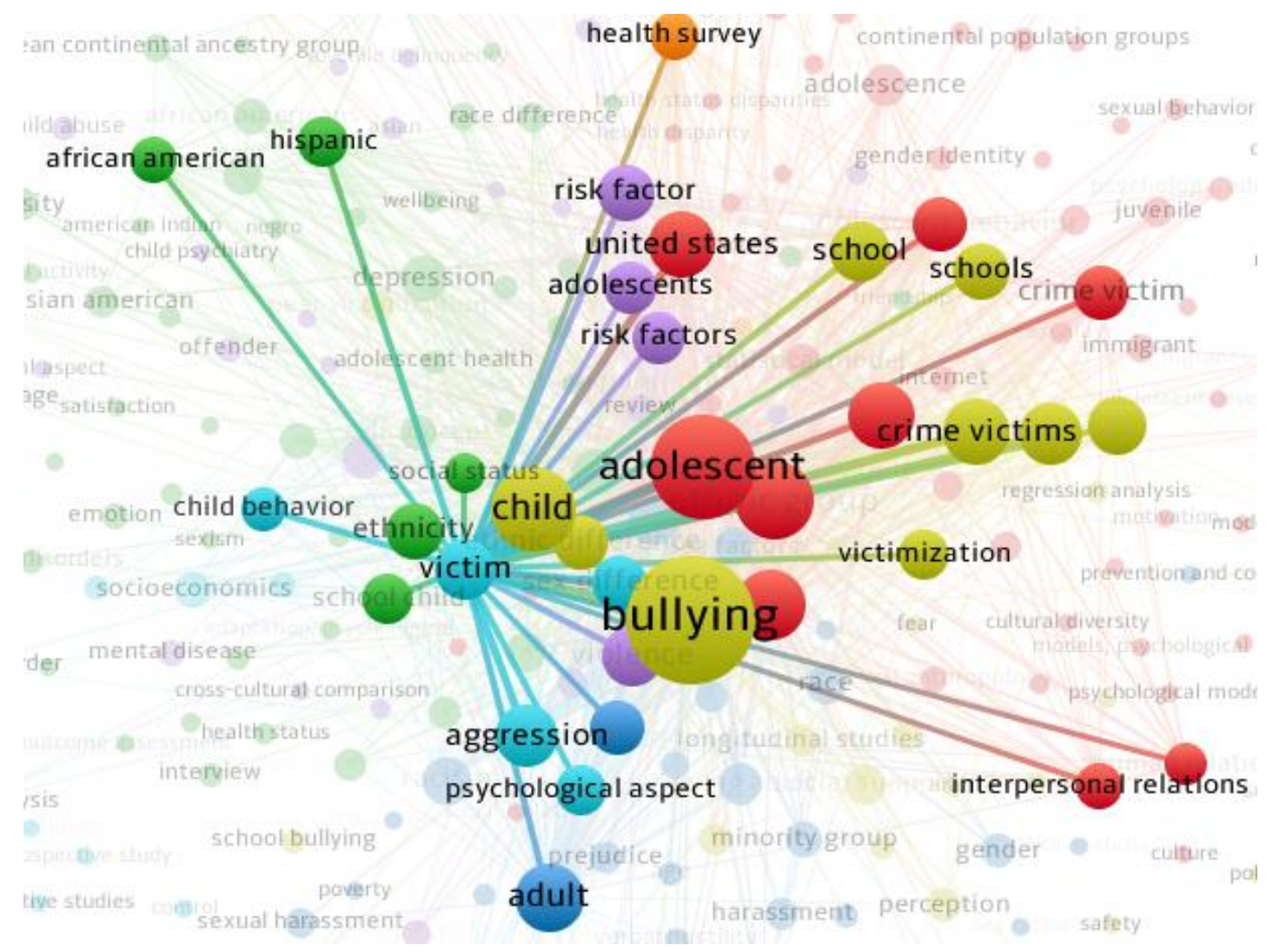

Figure 6. Co-occurrence analysis: bullying victims.

\section{Discussion and Conclusions}

The current society is characterized by the enormous speed at which the different areas that compose it evolve. In the educational landscape, the evolution at a technological level has generated important improvements in the teaching and learning processes. However, technology has also contributed to a considerable increase in the rates of violence by schoolchildren, with mobile devices and internet access being the most prolific focus of attacks [2].

In this way, harassment in general and cyberbullying in particular, are considered today as an important social problem [4] derived from the enormous negative consequences on young people who suffer from it [6,7,9-11].

Although the great diversity in the types of harassment makes it impossible to determine a specific profile [8], the review of the literature has shown that ethnic minorities are prone to suffer this type of violence [17], especially among first generation migrants [18].

Therefore, ethnic identity constitutes a differential factor in harassment [20], appearing to be accompanied generally by very poor socio-economic and cultural status [21], favoring depressive tendencies in the ethnic harassed [15], and drug consumption [24].

Starting from this complex social paradigm in which harassment has emerged as a problem of capital importance, in the scientific literature it has been possible to find some possible answers to counter this type of violence. Among these proposals are the enhancement of empathy with colleagues who suffer harassment [29], tutorial action [32], the dignification of teaching [28], and parental involvement [30,31].

To address student bullying, it is essential to identify the students that generate it and suffer from it [33], and to take measures that enable optimal prevention and proper treatment [34]. Therefore, it is especially interesting to assess the scientific base of knowledge, in order to use this question as a 
starting point in the elaboration of action plans that allow an optimal transfer between the scientific literature and implementation in practice.

In this way, the present study contributes in providing information on the state of racial or ethnic bullying issues with the greatest current impact. This contribution is made based on the analysis carried out in the Scopus and Web of Science databases and through systematic review [37].

In the analysis made from the published literature on the subjects that have been studied, it can be concluded that there are 831 relevant publications, with a notable increase in publication volume in recent years (2011-2019), highlighting the author Dewey Cornell (University of Virginia, Charlottesville, VA, USA). In addition, US publications are more prolific than the publications of the rest of the world, being directed to magazines on scholastic health and adolescence. Likewise, it is pertinent to highlight that most of these works are scientific articles published in journals, in areas related mainly to the field of psychology and health, with English being the main language used.

The analysis of co-occurrence based on the information provided by the title, the summary, and the keywords allows us to conclude that the bullying research is currently focused on the sample level in both adolescent groups and groups of children, with special emphasis on those that overlap racial or ethnic minorities. Ethnic studies are focused on the Hispanic-American, Caucasian, African, and Asian populations, with a special preponderance of the North American school context, while studies that focused on analysis of racial bullying are focused on the African-American population. In this way, there is a special predominance of studies that analyze the perspective of the victim from different perspectives, especially analyzing their ethnic origin, the inherent risk factors, the consequences caused by being a victim within the peer group, the context in which that occurs, and the socio-economic position of the victim.

Author Contributions: Conceptualization, A.J.M.G. and J.S.P.S.; methodology, A.-M.R.-G.; software, A.F.C.; formal analysis, A.F.C. and A.-M.R.-G.; investigation, A.F.C., A.J.M.G., J.S.P.S. and A.-M.R.-G.; writing-original draft preparation, A.F.C. and A.-M.R.-G.; writing—review and editing, A.F.C., A.J.M.G., J.S.P.S. and A.-M.R.-G.; visualization, J.S.P.S.; supervision, A.J.M.G. and A.-M.R.-G.

Funding: This research received no external funding.

Acknowledgments: We acknowledge the researchers of the research group AREA (HUM-672), which belongs to the Ministry of Education and Science of the Junta de Andalucia and is based in the Department of Didactics and School Organization of the Faculty of Education Sciences of the University of Granada.

Conflicts of Interest: The authors declare no conflict of interest.

\section{References}

1. Mason, G.; Czapski, N. Regulating cyber-racism. Melb. Univ. Law Rev. 2017, 41, 284-340.

2. Albert, M.J.; Ortegra, I.; García, M. Education in human rights: Ethical-civic formation of the social educators as way to anticipate the ciberbullying. Pedagog. Soc. Rev. Interuniv. 2017, 30, 181-194.

3. Tozun, M.; Babaoglu, A.B. Cyber bullying and its effects on the adolescent and youth health: A huge problem behind tiny keys Cyber bullying and health. J. Clin. Anal. Med. 2018, 9, 177-182. [CrossRef]

4. Strout, T.D.; Vessey, J.A.; DiFazio, R.L.; Ludlow, L.H. The Child Adolescent Bullying Scale (CABS): Psychometric evaluation of a new measure. Res. Nurs. Health 2018, 41, 252-264. [CrossRef] [PubMed]

5. Paget, A.; Parker, C.; Heron, J.; Logan, S.; Henley, W.; Emond, A.; Ford, T. Which children and young people are excluded from school? Findings from a large British birth cohort study, the Avon Longitudinal Study of Parents and Children (ALSPAC). Child Care Health Dev. 2018, 44, 285-296. [CrossRef] [PubMed]

6. Lee, J.; Hong, J.S.; Resko, S.M.; Tripodi, S.J. Face-to-Face Bullying, Cyberbullying, and Multiple Forms of Substance Use Among School-Age Adolescents in the USA. Sch. Ment. Health 2018, 10, 12-25. [CrossRef]

7. Li, Y.; Shi, J.R. Bullying and suicide in high school students: Findings from the 2015 California youth risk behavior survey. J. Hum. Behav. Soc. Environ. 2018, 28, 695-709. [CrossRef]

8. Tolsma, J.; Van Deurzen, I.; Stark, T.H.; Veenstra, R. Who is bullying whom in ethnically diverse primary schools? Exploring links between bullying, ethnicity, and ethnic diversity in Dutch primary schools. Soc. Netw. 2013, 35, 51-61. [CrossRef] 
9. Fisher, B.W.; Gardella, J.H.; Teurbe, A.R. Peer Cybervictimization Among Adolescents and the Associated Internalizing and Externalizing Problems: A Meta-Analysis. J. Youth Adolesc. 2016, 45, 1727-1743. [CrossRef] [PubMed]

10. Pulido, R.; Banks, C.; Ragan, K.; Pang, D.; Blake, J.J.; McKyer, E.L. The Impact of School Bullying on Physical Activity in Overweight Youth: Exploring Race and Ethnic Differences. J. Sch. Health 2019, 89, 319-327. [CrossRef]

11. Sampasa, H.; Chaput, J.P.; Hamilton, H.A.; Colman, I. Bullying involvement, psychological distress, and short sleep duration among adolescents. Soc. Psychiatry Psychiatr. Epidemiol. 2018, 52, 1371-1380. [CrossRef] [PubMed]

12. Rodríguez, A.J.; Solera, E.; Calmaestra, J. Psychological Predictors of Cyberbullying According to Ethnic-Cultural Origin in Adolescents: A National Study in Spain. J. Cross-Cult. Psychol. 2018, 49, 1506-1522. [CrossRef]

13. Heidelberger, L.; Smith, C. Low-Income, African American and American Indian Children's Viewpoints on Body Image Assessment Tools and Body Satisfaction: A Mixed Methods Study. Matern. Child Health J. 2018, 22, 1327-1338. [CrossRef] [PubMed]

14. Cardoso, J.B.; Szluk, H.S.; Goldbach, J.; Swank, P.; Zvolensky, M.J. General and Ethnic-Biased Bullying Among Latino Students: Exploring Risks of Depression, Suicidal Ideation, and Substance Use. J. Immigr. Minor. Health 2018, 20, 816-822. [CrossRef] [PubMed]

15. Merril, R.M.; Hanson, C.L. Risk and protective factors associated with being bullied on school property compared with cyberbullied. BMC Public Health 2016, 16, 145. [CrossRef] [PubMed]

16. Rodríguez, A.J.; Calmaestra, J.; Casas, J.A.; Ortega, R. Ethnic-Cultural Bullying Versus Personal Bullying: Specificity and Measurement of Discriminatory Aggression and Victimization Among Adolescents. Front. Psychol. 2019, 10, 46. [CrossRef] [PubMed]

17. Borraccino, A.; Charrier, L.; Berchialla, P.; Lazzeri, G.; Vieno, A.; Dalmasso, P.; Lemma, P. Perceived well-being in adolescent immigrants: It matters where they come from. Int. J. Public Health 2018, 63, 1037-1045. [CrossRef] [PubMed]

18. Vitoroulis, I.; Vaillancourt, T. Ethnic Group Differences in Bullying Perpetration: A Meta-Analysis. J. Res. Adolesc. 2018, 28, 752-771. [CrossRef] [PubMed]

19. Maffini, C.S.; Kim-Ju, G.M. Fighting and Bullying Among Asian Americans and Latinos: Testing the Roles of Self-Efficacy, Ethnic Identity, and Ethnicity. Youth Soc. 2018, 50, 1019-1036. [CrossRef]

20. Shea, M.; Wang, C.X.; Shi, W.N.; González, V.; Espelage, D. Parents and Teachers' Perspectives on School Bullying Among Elementary School-Aged Asian and Latino Immigrant Children. Asian Am. J. Psychol. 2016, 7, 83-96. [CrossRef]

21. Stone, A.L.; Carlisle, S.K. Racial bullying and adolescent substance use: An examination of school-attending young adolescents in the United States. J. Ethn. Subst. Abus. 2017, 16, 23-42. [CrossRef] [PubMed]

22. Wu, I.H.C.; Lyons, B.; Leong, F.T.L. How racial/ethnic bullying affects rejection sensitivity: The role of social dominance orientation. Cult. Divers. Ethn. Minor. Psychol. 2015, 21, 156-161. [CrossRef] [PubMed]

23. Henson, J.M.; Derlega, V.J.; Pearson, M.R.; Ferrer, R.; Holmes, K. African American students' responses to racial discrimination: How race-based rejection sensitivity and social constraints are relate to psychological reactions. J. Soc. Clin. Psychol. 2013, 32, 504-529. [CrossRef]

24. Roffee, J.A.; Wailing, A. Rethinking microaggressions and anti-social behaviour against LGBTIQ+ Youth. Safer Communities 2016, 15, 190-201. [CrossRef]

25. Moulin, D. Reported Experiences of Anti-Christian Prejudice among Christian Adolescents in England. J. Contemp. Relig. 2016, 31, 223-238. [CrossRef]

26. Davila, B. Critical race theory, disability microaggressions and Latina/o student experiences in special education. Race Ethn. Educ. 2015, 18, 443-468. [CrossRef]

27. Bae, H.O.; Choo, H.; Lim, C. Bullying Experience of Racial and Ethnic Minority Youth in South Korea. J. Early Adolesc. 2019, 39, 561-575. [CrossRef]

28. Limber, S.P.; Olweus, D.; Wang, W.J.; Masiello, M.; Breivik, K. Evaluation of the Olweus Bullying Prevention Program: A large scale study of US students in grades 3-11. J. Sch. Psychol. 2018, 69, 56-72. [CrossRef]

29. Wang, C.X.; La Salle, T.; Wu, C.R.; Do, K.A.; Sullivan, K.E. School Climate and Parental Involvement Buffer the Risk of Peer Victimization on Suicidal Thoughts and Behaviors Among Asian American Middle School Students. Asian Am. J. Psychol. 2018, 9, 296-307. [CrossRef] 
30. González, V.; Prendes, M.P. Cyberbullies: A quantitative research with secondary students. Pixel-Bit. Rev. Medios Educ. 2018, 53, 137-149.

31. Rose, C.A.; Espelage, D.L.; Monda, L.E.; Shogren, K.A.; Aragon, S.R. Bullying and Middle School Students With and Without Specific Learning Disabilities: An Examination of Social-Ecological Predictors. J. Learn. Disibilities 2015, 48, 239-254. [CrossRef] [PubMed]

32. Lai, T.J.; Kao, G. Hit, Robbed, and Put Down (but not Bullied): Underreporting of Bullying by Minority and Male Students. J. Youth Adolesc. 2018, 47, 619-635. [CrossRef] [PubMed]

33. Álvarez, J.A.; Belmonte, L.J.; Martos, A.; Barragán, A.B.; Simón, M.D. System to Detect Racial-Based Bullying through Gamification. Front. Psychol. 2016, 7, 1791.

34. Cobo, M.J.; López, A.G.; Herrera, E.; Herrera, F. An approach for detecting, quantifying, and visualizing the evolution of a research field: A practical application to the fuzzy sets theory field. J. Informetr. 2011, 5, 146-166. [CrossRef]

35. Rodríguez-García, A.M.; Trujillo, J.M.; Sánchez, J. Impacto de la productividad científica sobre competencia digital de los futuros docentes: Aproximación bibliométrica en Scopus y Web of Science. Rev. Complut. Educ. 2019, 30, 623-646. [CrossRef]

36. Hinojo-Lucena, F.J.; Aznar-Díaz, I.; Cáceres-Reche, M.P.; Romero-Rodríguez, J.M. Artificial Intelligence in Higher Education: A Bibliometric Study on its Impact in the Scientific Literature. Educ. Sci. 2019, 9, 51. [CrossRef]

37. Moher, D.; Shamseer, L.; Clarke, M.; Ghersi, D.; Liberati, A.; Petticrew, M.; Stewart, L.A. Preferred reporting items for systematic review and meta-analysis protocols (PRISMA-P) 2015 statement. Syst. Rev. 2015, 4, 1. [CrossRef]

38. Spriggs, A.L.; Iannotti, R.J.; Nansel, T.R.; Haynie, D.L. Adolescent Bullying Involvement and Perceived Family, Peer and School Relations: Commonalities and Differences Across Race/Ethnicity. J. Adol. Health 2007, 41, 283-293. [CrossRef] [PubMed]

39. Sawyer, A.L.; Bradshaw, C.P.; O’Brennan, L.M. Examining Ethnic, Gender, and Developmental Differences in the Way Children Report Being a Victim of "Bullying" on Self-Report Measures. J. Adol. Health 2008, 58, 106-114. [CrossRef] [PubMed] 